the Faculty of Forestry, University of British Columbia. Newly elected Councillors are: James R. Collins, Reid, Collins \& Associates Ltd., Consulting Foresters, Vancouver; Nicholas V. Mason, Forester, i/c Management, B.C. Forest Service, Kamloops; J. A. Kenneth Reid, Ass't. District Forester, B.C. Forest Service, Vancouver; and W. Edward L. Young, Forester, i/c Surveys \& Inventory Div. B.C. Forest Service, Victoria. F. M. Knapp, Faculty of Forestry, U.B.C., was re-appointed Registrar.

\title{
Forest MENSURation Group
}

Meetings of this group were held during 1962 Annual Meetings of the Canadian Institute of Forestry and the Society of American Foresters. Under the stimulus of Professor Harold Young a remarkable revival of interest in mensuration has been evident recently in Canada and the United States. Messrs. T. G. Honer and L. Sayn-Wittgenstein of the Department of Forestry, Ottawa, Ont. have prepared an excellent statement of problems in forest mensuration that was distributed to all members of the Group. It is expected that Canadian foresters interested in forest measurements will meet again during the 1963 Annual Meeting, Oct. 6-10 at Halifax, N.S. The Forest Management Division of the Society of American Foresters will have a session on forest mensuration during the S.A.F. Annual Meeting in Boston Oct. 20-23. Anyone particularly interested in the field of forest measurements should contact Professor Young at the School of Forestry, Univ. of Maine, Orono, Maine, or myself at the University of British Columbia, Vancouver.

J. H. G. SMTrH

\section{TECHNICAL NOTE \\ Mulching and Screening of White Spots on CUT-Over aNd BURNed-Over LAND ${ }^{1}$}

BY J. W MCLEOD 2

Observations over a 10-year period show that white spruce seedlings survived better with combined mulching and screening of seed spots than with either treatment alone.

The study was carried out at the Acadia Forest Experiment Station, near Fredericton, N.B. on a fresh to moist site which previously supported a mixture of red spruce and balsam fir. The area was clear cut in 1950 and burnt the following May. The white spruce seed was sown on 64 spots, each about 9 inches square, prepared by lightly scraping away the charred litter. Ten seeds were sown on each spot, then half the spots were mulched with a layer of sawdust about 3/16-inch thick. Conical wire screens with a $1 / 4$-inch mesh were used on one-half of each mulched or unmulched spot to exclude birds and rodents; the screens were removed in 1953. The treatments were arranged according to a split plot design. Details of establishment are given in a previous paper (McLeod, 1953).

A summary of the data supporting the observations is presented in Table 1. Survival has been best on plots which were both mulched and screened; survival after either mulching or screening alone was much poorer.

\footnotetext{
${ }^{1}$ Canada, Department of Forestry, Forest Research Branch Contribution Number 501.

Research Officer, Fredericton, New Brunswick.
} 
In the first year the mulched spots showed greater stocking than did the screened ones; three years later stocking was better on the screened. Mortality had stabilized two years after seeding on the screened spots but not on the mulched. The reason for continued reduction in stocking on the latter spots was not evident.

Average growth has been slow. In 1960 the tallest seedling per spot averaged only three feet in height, but some seedlings had grown about one foot per year in 1959 and 1960.

Although the combined sawdust and screen coverings produced outstanding stocking, research is needed to develop means of achieving similarly good results with cheaper treatments.

TABLE 1

INFLUENCE OF MULCHING AND SCREENING ON THE Establishment and Survival of White Spruce

\begin{tabular}{|c|c|c|c|c|}
\hline \multirow[t]{2}{*}{$\begin{array}{c}\text { Date of } \\
\text { Measurement }\end{array}$} & \multicolumn{4}{|c|}{ Stocking in per cent } \\
\hline & $\begin{array}{c}\text { Malched and } \\
\text { screened }\end{array}$ & $\begin{array}{l}\text { Screened only } \\
\text { not mulched }\end{array}$ & $\begin{array}{l}\text { Mulched only } \\
\text { not screened }\end{array}$ & Untreated \\
\hline August, 1951 & 100 & 81 & 94 & 56 \\
\hline September, 1952 & 87 & 50 & 44 & 12 \\
\hline July, 1953 & 87 & 37 & 37 & 12 \\
\hline August, 1954 & 87 & 37 & 19 & 12 \\
\hline August, 1960 & 87 & 37 & 12 & 12 \\
\hline $\begin{array}{l}\text { Per cent decrease in } \\
\text { stocking, 1951-1960 }\end{array}$ & 13 & 44 & 82 & 44 \\
\hline
\end{tabular}

REFERENCE

McLEOD, J. W. 1953. Direct seeding of white spruce on a controlled burn in southern New Brunswick, Canada, Department of Northern Affairs and National Resources, Forestry Branch, For. Res. Div., Silv. Leafl, No. 97.

\section{FAY HARTMAN}

Rarely does our profession suffer so severe a shock as it has through the tragic death of Fay Hartman.

Scarcely over the threshold of what promised to be a brilliant career as a wildlife biologist, Fay was killed when the light aircraft in which he was making a field survey crashed in the wilderness, not far from his birthplace in northern British Columbia.

Those who had the pleasure of knowing him personally found that Fay's natural sincerity and good sense, his warm generosity and constant good humour, made him a delightful personality and cherished friend. Others, who encountered him professionally, found his truly exceptional human qualities were coupled with an inspiring competence and enthusiasm in the study of wildlife 